\title{
HEAD UUT TÜVIAASTAT!
}

Oktoobrikuu Keeles ja Kirjanduses andis Arne Merilai hea ülevaate ingliskeelsete mõistete core text ('tuumtekst') ja seminal work ('viljastav teos') mitte üksühese eesti vaste tüvitekst vohamisest (sõnasõnaline vaste oleks tuumtekst) ja selle uutest tähendusvarjunditest. ${ }^{1}$ Jaan Unduski loodud, algselt üsna konkreetselt F. R. Kreutzwaldi eepost „Kalevipoeg” tähistanud tüviteksti mõistet tarvitatakse praegu mis tahes kanooniliste tekstide kohta. Ka Merilai ise liidab selle mõnele uuele objektile (A. H. Tammsaare „aga-ometi” ja Marie Underi ballaadid) ja lisab varjundeid, mistap järeldan, et muretsemiseks mõiste hägustumise pärast ei ole tema arvates põhjust. Tõesti, tunneme arvukalt näiteid sellest, kuidas mõni mõiste mitme valdkonna vahel inspireerival moel triivib. Näiteks selsamal sõnal kaanon, mis pärineb kreekakeelsest sõnast $\varkappa \alpha v \omega ́ v$ ehk reegel, on oma spetsiifiline tähendus nii kirjandusteaduses, teoloogias kui ka muusikas. Suurepärane, kui ka kirjandusteadus ise suudab maailmale või vähemasti ühele keeleruumile sedavõrd elujõulisi mõisteid kinkida. See, et kõige „kõvemad” teadusedki ei suuda maailma poeetiliste metafooride abita seletada, on lausa omaette teema: suur pauk, universumi kärgstruktuur ... ja tüvirakud!

Tüvirakk on õigekeelsussõnaraamatu järgi „rakk, mis on võimeline end taastootma, lõplikult diferentseerumata rakk". ${ }^{2}$ Tüviraku puhul on kõik võimalik, just tüvirakkudest tekivadki mitmesuguste ülesannetega organid. ${ }^{3}$ Tüvi-

\footnotetext{
${ }^{1}$ A. Merilai, Tüviteksti mõistest. - Keel ja Kirjandus 2017, nr 10, lk 737-752.

${ }^{2} \mathrm{http}: / /$ eki.ee/dict/qs/index.cgi?Q=t\%C3\% BCvirakk (24. XI 2017).

${ }^{3}$ Vt P-R. Larm, Ellujäämine ei ole iseenesestmõistetav. [Intervjuu Siim Paukli-
}

teksti mõiste ise on samuti niisugune rakk.

Hiljuti jäi nimelt silma üks põnev „tüvirakumutatsioon”. See oli veebruaris, kui Tammsaare ja Vilde Sõprade Selts andis teater Variuse eestvedajale Heidi Sarapuule „Klassiku sõbra” auhinna. Toomas Haugi kummarduskõnes leidus niisugune mõttekäik: „Kui mõtlen „Variuse” peale, siis meenuvadki kõigepealt algusajad, sealhulgas legendaarne etendus „Arbujate aegu” 1988. aastal, mida mängiti menukalt mitmes muuseumis. [---] Nii nagu „Kalevipoeg” ja „Tõde ja õigus” on meie tüvitekstid, nii on XX sajandi 1930. aastad, muu hulgas seesama arbujate aeg, meie tüviaeg. Tarvitseb ainult kujutleda, et selle ajani jõudmist, sellele ajaharjale tõusmist poleks olemas olnud, ja tekib tunne, nagu libiseks pind jalge alt. See on tüviaeg, millest tuleb mingi tabamatu ajaloo- või identiteedimeelega kinni hoida, ja Heidi Sarapuu looming on siin üks sellise kinnihoidmise ning selle kinnihoidmiselamuse teistega jagamise kaunis näide. [---] Kui läheme „Variuse” etendusele, [---] siis võime olla kindlad, et me mingis vormis, otse või kaude, puutume ikka ja jälle kokku oma tüviajaga."4

Miks „tüviaeg”, kas nii saab öelda? Tüviaega eristab ju tüvitekstist kõigepealt suhteline ähmasus - ei ole päris selge, millal see algab ja lõpeb. Vähe sellest - kui tüviteksti tiitli au broneeriti esialgu ühele teosele, siis rahva ja riigi elus on kindlasti rohkem kui üks tüviaeg. Kui tüvesid on metsatäis, siis on, mille vastu selga toetada! Eri aegadel on

\footnotetext{
niga.] - Sirp 4. VIII 2017, http://sirp.ee/s1artiklid/c7-kirjandus/ellujaamine-ei-ole-iseenesestmoistetav/ (24. XI 2017).

${ }^{4}$ T. H a u g, Kummardus Heidi Sarapuule. - Looming 2017, nr 3, lk 389-390.
} 
moes eri tüved: ärkamisajal hõllandus eestlastele muistne Kungla õnneriik, 1930. aastatel võidukas viikingiajastu ja viimastel aastatel võib tõepoolest täheldada 1930. aastate esiletõusu, sealt võetakse šnitti nii fassongis kui ka retoorikas. Miks just need tüviajad? Samahästi võiks eestlaste rahvuslik tüviaeg olla aastad 1917-1920 või laulva revolutsiooni aastad, aga tundub, et tõesti murrangulisest perioodist tüviaega ei saa - liiga ärev. Tüviaeg kätkeb unistust, see on natuke nagu roosamanna, nagu helesinised mäed. Liigne kiindumine tüviaega võib paraku ebaterveks osutuda, ivanoravalik kompleksivaba lähenemine on kindlasti mõistlikum viis tüviajaga toimetulekuks.

Tõtt-öelda olen isegi ühte tüviaega kiindunud. Lähtudes tüviteksti kitsast tähendusest, püüan sealjuures ka tüviaja au ühele kindlale aastale hoida. See on 1857. aasta. Sel aastal olid teadupärast Prantsusmaal kohtu all kaks ebamoraalseks peetud teost, Charles Baudelaire’i „Les Fleurs du mal” („Kurja lilled”) ja Gustave Flaubert'i „Madame Bovary". Ja ka meil Eestis oli kirjandusliku mõtte areng sealmaal, et ilmuma hakkas kaks pöördumatute tagajärgedega nähtust: ajaleht Pärnu Postimees, mis tähendas järjepideva eestikeelse ajakirjanduse algust ja laialt levinud müüdi järgi eestlastele nime andmist, ning eestlaste rahvuseepos „Kalevipoeg", mis tähendas Schultz-Bertramit parafraseerides, et nüüd on kõik võidetud. Tsensuuriga said rinda pista mõlemad. Kui tüviteksti puhul on selle „üksikud laused ja eriti motiivid ning tegelasstruktuurid [---] rahvuskehasse sööbinud sedavõrd tugevasti, et neid eemaldades lammutaksime rahvuslikku psüühikat ennast", ${ }^{5}$ siis sama võib öelda 1857. aasta kui tüviaasta kohta.

${ }^{5} \mathrm{~J}$. Undu s k, Rahvaluuleteksti lõppematus. Felix Oinas, soome meetod ja intertekstuaalne „Kalevipoeg”. [Järelsõna.] - F. Oinas, Surematu Kalevipoeg. Tallinn: Keel ja Kirjandus, 1994, lk 148.
Iseasi, kas tüviteksti mõiste laiendamine, et mitte öelda tüviteksti lõppematus, on see, mida vajatakse. Kui meditsiini vallast veel üks analoog tuua, siis tüvirakkudest arenevad paraku ka kasvajad. Tasub püüelda mõistelise selguse poole.

Viimaks mõni sõna seoses kimbatusega, mis tabab neid, kes inglise keeles kirjutades-rääkides aduvad, et miski tüviteksti mõistest tõlkes kaotsi läheb. Asko Künnapi luuletusest „Ja me ei surunud peale oma jumalaid" leiame tüvitekstiga seoses järgmised read:

Me sõlmisime vaikuse, sulgesime sõnad, haabjad tahusime tüvitekstidest, ühes rändraamatuparvedega kadusime sellest metsast, mis võlvub unedes tume. Ja me ei surunud peale oma jumalaid. ${ }^{6}$

Adam Culleni tõlkes inglise keelde kõlavad lõpuread nii:

We crisscrossed silence, closed up words, congealed dugouts from trunk texts, with the flocks of migrating books we vanished

from that forest, which arches dark in dreams.

And we forced not our gods upon them. ${ }^{7}$

Tüviteksti vaste ei ole siin core text, rääkimata seminal text'ist, vaid ongi lihtsalt sõnasõnaline trunk text. Ehk on tegu esimese tüvimõistega, mis väljub eesti keeleruumist? Sellest hetkest saaks siis küll eesti kirjandusteaduse tüviaeg.

\section{PILLE-RIIN LARM}

${ }^{6}$ Lõpmatuse lävel. Eesti luuletajad Niguliste kirikus. The Brink of Infinity. Estonian Poets in St. Nicholas' Church. Koost V. Kivisilla. Tallinn: HeadRead MTÜ, 2015, lk 60.

${ }^{7}$ Lõpmatuse lävel, lk 61. 